Article

\title{
Contemporary Pyrogeography and Wildfire-Climate Relationships of South Dakota, USA
}

\author{
Darren R. Clabo
}

Department of Civil and Environmental Engineering, South Dakota School of Mines and Technology, Rapid City, SD 57701, USA; darren.clabo@sdsmt.edu

Received: 17 April 2018; Accepted: 17 May 2018; Published: 25 May 2018

\begin{abstract}
A recent wildland fire history and climate database was compiled for South Dakota, USA (SD). Wildfires are generally a warm season phenomenon across central and western SD while eastern SD exhibits a spring peak in annual wildfire activity. It is hypothesized that regional climate and land use are the two primary drivers of the spatiotemporal wildfire distribution across the state. To assess the relative impacts of climate to wildfire activity, Spearman's rank order correlation coefficients were calculated for monthly values of temperature, precipitation, and the Palmer Drought Modified Index (PMDI) as compared to both monthly area burned and numbers of fire starts data for each of the nine climate divisions in South Dakota. Results show statewide variations in significant correlations but positive temperature anomalies, negative precipitation anomalies, and negative values of the PMDI were most frequently associated with months showing substantial area burned and large numbers of wildfire starts. Time-lagged significant correlations were also seen implying month(s)-ahead predictive capabilities. Positive PMDI values were most significantly correlated to warm season wildfire activity suggesting that the influence of drought on wildfires within SD may be limited to the summer months.
\end{abstract}

Keywords: wildfire; climatology; pyrogeography

\section{Introduction}

Knowledge of wildfire-climate relationships is vital in understanding the favorable environmental conditions for large wildfire growth. Climate is a primary control on local weather [1] and vegetation/fuel conditions [2,3] thereby largely dictating wildfire seasonality, location, and severity [4]. Anthropogenic factors (i.e., land use, ignitions) also impact regional wildfire climatology $[5,6]$. Wildfires are not equally distributed globally $[7,8]$ with the most frequent wildfires occurring in regions where fuel availability meets favorable climatic conditions. Furthermore, the specific spatial and temporal characteristics of wildfire differ substantially from region to region around the world [9-12].

Mirroring global wildfire heterogeneity, the wildfire climatology of the conterminous United States (US) varies considerably in space and time. Wildfires occurring over the western US are typically a warm season phenomena [13] with intra-seasonal variation based on latitude: wildfires largely peak across southern, central, and northern areas of the region in June, July, and August, respectively [14,15]. Notable exceptions include the California Coast Chaparral which has a peak in fire activity in the fall months and the Southwest Plateau which sees an early fire season running from late winter through early spring [15]. Fire activity in the western Great Plains typically peaks during the warm season [15]; however, other portions of the Great Plains including the High Pains, Lake Agassiz region, Flint Hills, central Great Plains, and Southwestern Tablelands also show a propensity for increased fire activity during the spring months [16]. Wildfires across the eastern US, including the Appalachian region, see yearly peaks in fire activity during October and November as well as during March and April $[17,18]$. 
The temporal distribution of wildfires, especially across the grasslands that dominate the Great Plains, may be linked to plant phenology. Wildland fuels, both living and dead, all inherently contain some level of moisture and before ignition can occur, the moisture within the fuel must be removed $[19,20]$. The amount of moisture within a living fuel is driven by the annual growth cycle which in turn is determined in part by temperature, precipitation, relative humidity, and solar radiation [21]. These same environmental variables also control the amount of moisture contained within dead plant material [22]. During the annual growing cycle of the herbaceous fuels, the proportion of live-to-dead material within the fuel matrix impacts the ignition and spread efficiencies with higher percentages of live material being more detrimental to fire propagation [20]. Although natural ignitions may be infrequent during the early spring months, increases in wildfires across the region are still seen owing to the cured nature of the fine fuels.

The relationship between wildfire and climate patterns differs across the unique landscapes of the US. High wildland fire activity across the closed canopy forests of the western US has been linked to anomalously dry conditions over the previous $1-2$ years [14,15,23-25]. Wildfire severity in these dense and/or mid- to high-elevations forests is largely a function of climate variability and its subsequent effects on the fuels [26]. This contrasts with open canopy forests, grasslands, and shrublands which show relationships between high wildfire activity and anomalously high moisture in the year prior, if short-term dry conditions are observed just before and during the wildfire season itself $[14,15,25,27]$. Positive temperature anomalies have also been linked to concurrent increases in wildfire activity $[23,28,29]$.

The purpose of this study is to examine the contemporary wildfire climatology and pyrogeography of South Dakota and to establish linkages between wildfire and climate metrics such as temperature, precipitation, and drought. South Dakota is centered within the Great Plains but contains substantial longitudinal variation in climate [30], topography, and land use [31]. It is hypothesized that regional differences will exist within South Dakota in wildfire seasonality and frequency due to these variations. Furthermore, it is hypothesized that positive temperature anomalies, moisture deficits, and drought are all significantly correlated to statewide increases in wildfire frequency and area burned regardless of time of year.

\section{Experiments}

Wildfire data for this study were collected from the Great Plains Interagency Dispatch Center, the Black Hills National Forest, volunteer fire department incident reports, and state reports to the National Association of State Foresters. These data include wildfires on both public and private lands. The data were combined to form a single wildfire database consisting of 16,908 wildfires encompassing 659,344 ha $(1,629,274$ acres). The data were quality-controlled to the extent possible with duplicate entries and entries with invalid geospatial information being manually removed. If questionable entries remained, the author contacted the relevant land managers to verify the wildfire entry and, in several cases, Landsat imagery (https://landsatlook.usgs.gov/viewer.html) was used to visually identify fire scars. Data retained include fire name, fire start date, initial fire latitude/longitude (presumed to be the ignition point), final fire size, and fire cause (human, lightning, unknown, or other). For this study, human ignitions include equipment use, smoking, camp fires, debris burning, railroads, arson, child-caused fires, fireworks, powerlines, and structure fires that have spread to the wildland. It is important to note that the wildfire ignition data contained within this study rely on information provided by suppression resources; that is, only wildfires that were actively responded to were included. It is likely that additional fires occurred but were extinguished naturally without human intervention.

Geospatial software (ArcMap 10.2.2, Esri, Redlands, CA, USA) was utilized to partition the fire entries into their respective South Dakota climate divisions, as described by Guttman and Quayle [32]. There are nine distinct climate divisions within South Dakota (Figure 1): Climate Division 1 (Northwest, NW), Climate Division 2 (Northcentral, NC), Climate Division 3 (Northeast, NE), Climate 
Division 4 (Black Hills, BH), Climate Division 5 (Southwest, SW), Climate Division 6 (Central, C), Climate Division 7 (Eastcentral, EC), Climate Division 8 (Southcentral, SC), and Climate Division 9 (Southeast, SE). Due to limitations in the fire databases, only data from 1998-2016 were included for South Dakota Climate Divisions 1-3 and 5-9 while South Dakota Climate Division 4 contains data from 1987-2016. Climate Division 4 includes additional years as the majority of the land ownership within the division belongs to the Black Hills National Forest which has compiled more robust fire data over a longer period of time than the other sources.

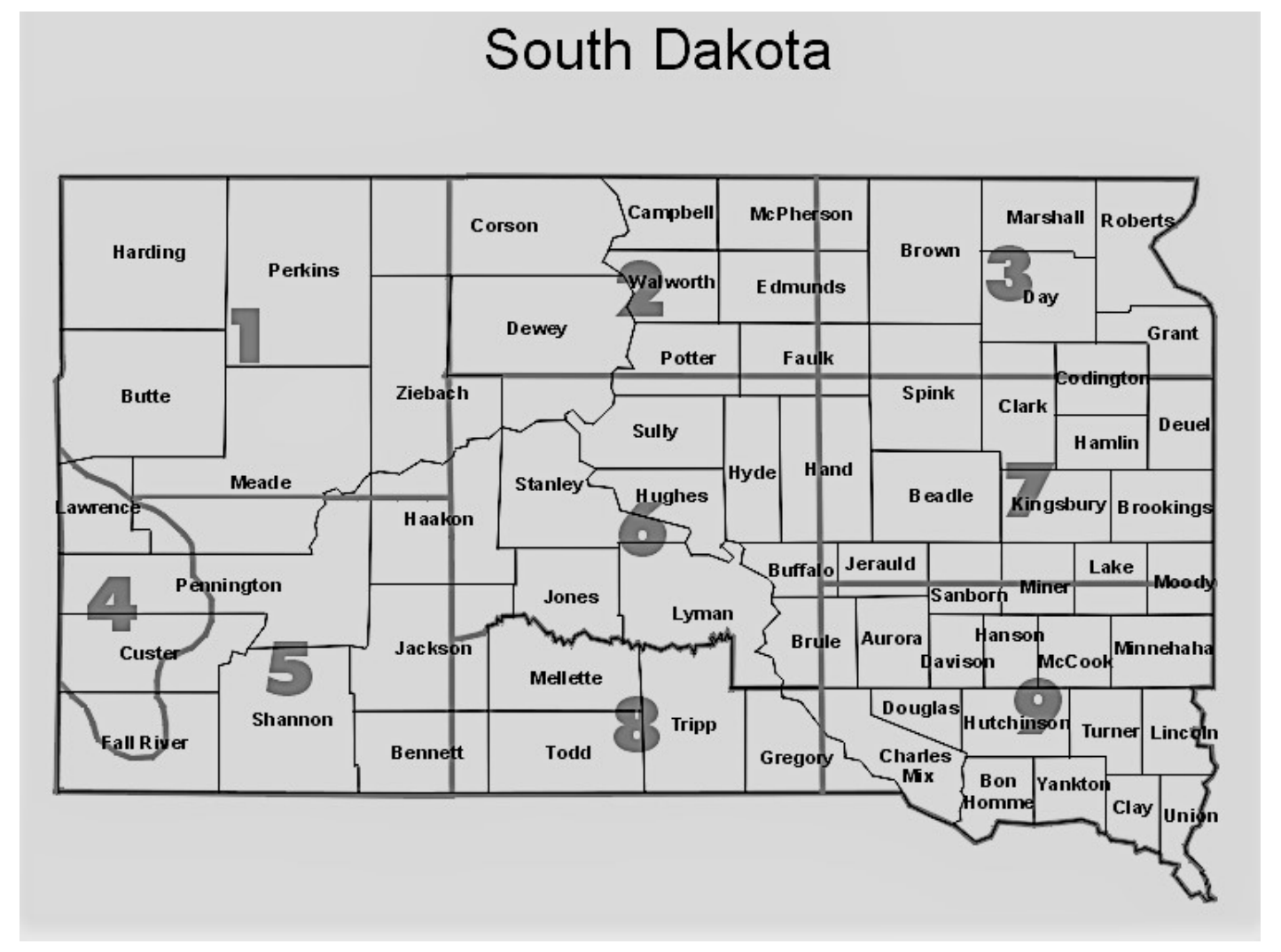

Figure 1. The nine climate divisions of South Dakota with underlying counties named and outlined. Figure adapted from the Climate Prediction Center, National Oceanic and Atmospheric Administration.

The climate of South Dakota is of continental type with four distinct seasons including hot summers and cold winters [30]. For reference, the monthly precipitation and temperature averages for the period of study are given in Figure 2 for each climate division. Monthly climate data for South Dakota were obtained from the National Oceanic and Atmospheric Administration's National Centers for Environmental Information (NCEI) for each climate division within the state. Climate data acquired include temperature, precipitation, and the Palmer Modified Drought Index (PMDI). The PMDI is positive for abnormally wet periods and negative for abnormally dry periods with higher absolute values depicting increasingly abnormal conditions. It is the favored drought index for this study as it is readily available through the NCEI and can be used in a real-time, operational setting [33,34]. There are both strengths and weaknesses in using climate divisions for expressing the climatic variables with the primary weaknesses relating to the disparity between the climate division boundaries and climatological homogeneity, complex terrain, and inconsistencies in the number of reporting stations between divisions [32]. 


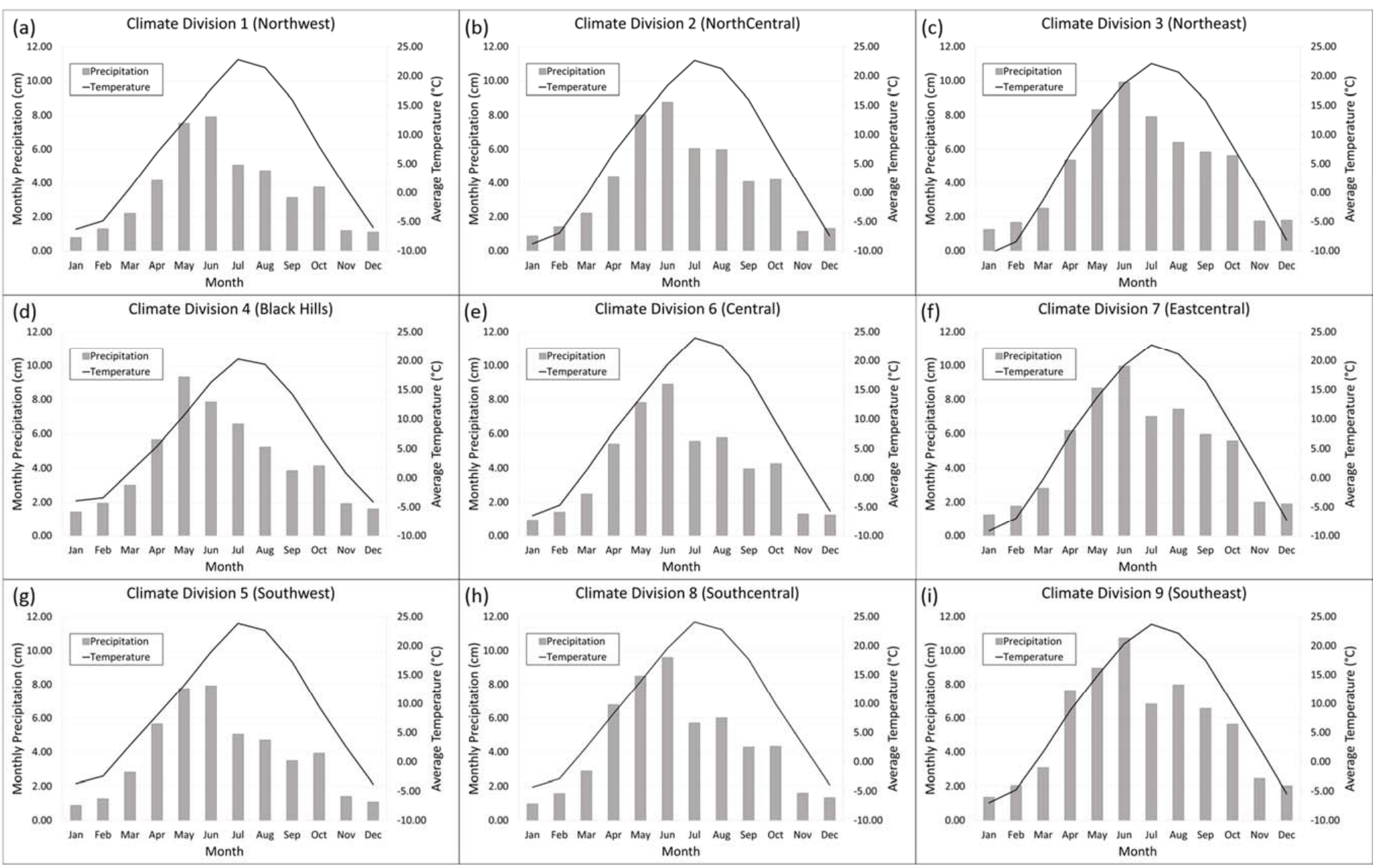

Figure 2. Monthly average precipitation and temperature for South Dakota: (a) Climate Division 1 (Northwest); (b) Climate Division 2 (Northcentral); (c) Climate Division 3 (Northeast); (d) Climate Division 4 (Black Hills); (e) Climate Division 6 (Central); (f) Climate Division 7 (Eastcentral); (g) Climate Division 5 (Southwest); (h) Climate Division 8 (Southcentral); (i) Climate Division 9 (Southeast). 
Table 1. Climate variable nomenclature descriptions, sign conventions, and usage examples. This table is to be used in conjunction with Tables 2 and 3.

\begin{tabular}{|c|c|c|c|c|}
\hline Climate Metric & Sign (+ or -) Convention & Variable & Time Lag & Variable Example \\
\hline \multirow{2}{*}{$\begin{array}{l}\text { Palmer Modified Drought } \\
\text { Index (PMDI) }\end{array}$} & \multirow{2}{*}{$\begin{array}{l}\text { (+) Abnormally wet conditions are significantly correlated }(p<0.05) \text { to larger number of fire starts or } \\
\text { area burned } \\
(-) \text { Drought conditions are significantly correlated }(p<0.05) \text { to larger number of fire starts or area burned }\end{array}$} & $P M D I_{i}$ & Concurrent month & May 2016 wildfire data vs. May 2016 PMDI data \\
\hline & & $P M D I_{i-1}$ & Previous month & May 2016 wildfire data vs. April 2016 PMDI data \\
\hline \multirow{4}{*}{ Precipitation } & \multirow{4}{*}{$\begin{array}{l}\text { (+) Precipitation excesses are significantly correlated }(p<0.05) \text { to larger number of fire starts or area burned } \\
(-) \text { Precipitation deficits are significantly }(p<0.05) \text { correlated to larger number of fire starts or area burned }\end{array}$} & $P_{i}$ & Concurrent month & $\begin{array}{l}\text { May } 2016 \text { wildfire data vs. May } 2016 \\
\text { precipitation data }\end{array}$ \\
\hline & & $P_{i-1}$ & Previous month & $\begin{array}{l}\text { May } 2016 \text { wildfire data vs. April } 2016 \\
\text { precipitation data }\end{array}$ \\
\hline & & $P_{i-3}$ & $\begin{array}{l}\text { Cumulative precipitation from } \\
\text { prior } 3 \text { months }\end{array}$ & $\begin{array}{l}\text { May } 2016 \text { wildfire data vs. February-April } 2016 \\
\text { cumulative precipitation data }\end{array}$ \\
\hline & & $P_{i-12}$ & $\begin{array}{l}\text { Cumulative precipitation from } \\
\text { prior } 12 \text { months }\end{array}$ & $\begin{array}{l}\text { May } 2016 \text { wildfire data vs. May 2015-April } 2016 \\
\text { cumulative precipitation data }\end{array}$ \\
\hline \multirow{2}{*}{ Temperature } & \multirow{2}{*}{$\begin{array}{l}\text { (+) Abnormally warm conditions are significantly correlated }(p<0.05) \text { to larger number of fire starts or } \\
\text { area burned } \\
(-) \text { Abnormally cold conditions are significantly correlated }(p<0.05) \text { to larger number of fire starts or } \\
\text { area burned }\end{array}$} & $T_{i}$ & Concurrent month & $\begin{array}{l}\text { May } 2016 \text { wildfire data vs. May } 2016 \\
\text { temperature data }\end{array}$ \\
\hline & & $T_{i-1}$ & Previous month & $\begin{array}{l}\text { May } 2016 \text { wildfire data vs. April } 2016 \\
\text { temperature data }\end{array}$ \\
\hline
\end{tabular}


To establish a linkage between wildfires and climate, Spearman's rank order correlation coefficients were calculated with two-tailed significance values between monthly climate data and monthly wildfire data (both area burned and number of ignitions) for each of the nine climate divisions. There is no expectation of normality within the monthly fire data and therefore Spearman's method was utilized in this study [35]. The wildfire data for each month of the period of record was ranked against that given month's climate data (precipitation, $P_{i}$; temperature, $T_{i}$; PMDI, $P M D I_{i}$ ) and the previous month's climate data (precipitation, $P_{i-1}$; temperature, $T_{i-1}$; PMDI, $P M D I_{i-1}$ ). Additionally, the wildfire data for each month of the period of record was ranked against accumulated precipitation for the three months preceding the given fire month $\left(P_{i-3}\right)$, and for the twelve months preceding the given fire month $\left(P_{i-12}\right)$. The effects of precipitation on the wildland fuels may be long lasting and therefore the lagged precipitation values are included. These long-duration effects are not expected for temperature and the PMDI already incorporates prior climate information including temperature and precipitation. Descriptions and examples of these variables are given in Table 1. Correlations were then calculated for all paired rankings.

\section{Results}

Wildfire occurrence shows strong seasonal dependence within the state of South Dakota but this seasonality differs among climate divisions and varies considerably by longitude and to a lesser degree by latitude (Figure 3). Wildfires are most common during the warm season throughout central and western SD with moderate wildfire activity extending into the fall months. Wildfires typically peak in both numbers and area burned during the spring months across eastern South Dakota. Lightning-ignited wildfires are rare across eastern South Dakota while they are relatively common across central and western South Dakota during the warm season. Notably, lightning causes more than $50 \%$ of the wildfires in Climate Division 4 (Black Hills) from June-September.

Seasonality and cause of ignition are two important aspects of the pyrogeography of an area although the year-to-year variability in climatic and/or meteorological conditions likely drive local wildfire frequency and severity. These relationships are explored in both Tables 2 and 3. Table 2 shows the significant $(p<0.05)$ Spearman's rank order correlations for the monthly climate variables (temperature, precipitation, and PMDI) as compared to the monthly area burned. Table 3 shows the significant rank correlations between the monthly climate variables and monthly number of ignitions. Positive (negative) values for PMDI indicate significant rank correlations between abnormally wet (dry) periods and the wildfire data, positive (negative) values of temperature $(\mathrm{T})$ indicate significant rank correlations between above (below) average temperatures and the wildfire data, and positive (negative) values of precipitation $(\mathrm{P})$ indicate significant rank correlations between precipitation deficits (surpluses) and the wildfire data. Significant rank correlations were not seen in the data for every month (as denoted by the * in Tables 2 and 3 ) and for many of the months, namely during the warm season, significant correlations are seen for many climate variables for each climate division. The impacts of the anthropogenic factors (i.e., land use, ignitions) on wildfires are not included although these factors likely have significant importance in both wildfire frequency and size [36]. 


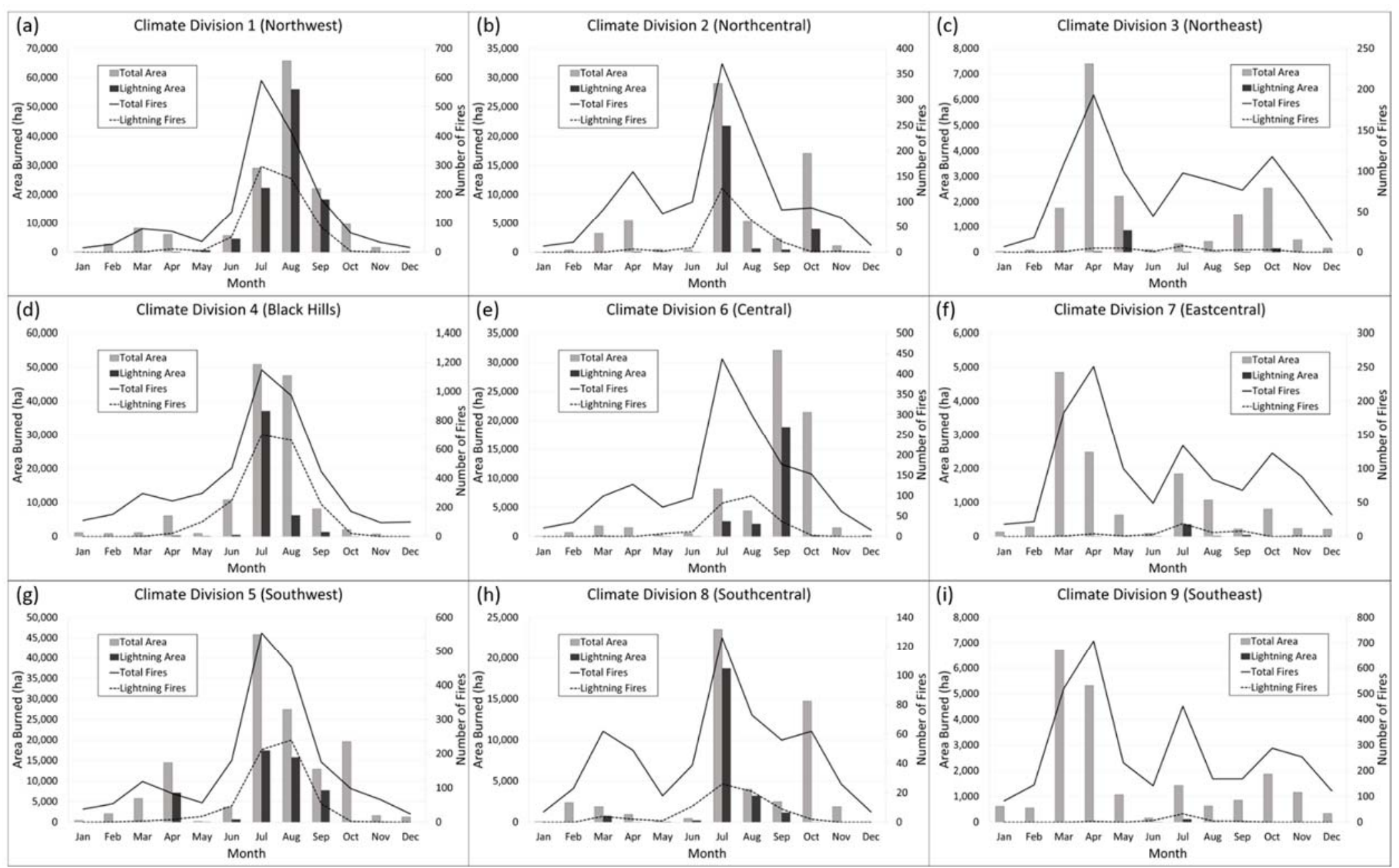

Figure 3. Monthly total hectares burned and number of fire starts for South Dakota: (a) Climate Division 1 (Northwest); (b) Climate Division 2 (Northcentral); (c) Climate Division 3 (Northeast); (d) Climate Division 4 (Black Hills); (e) Climate Division 6 (Central); (f) Climate Division 7 (Eastcentral); (g) Climate Division 5 (Southwest); (h) Climate Division 8 (Southcentral); (i) Climate Division 9 (Southeast). Note: the scale of the vertical axes differs between panels. 
Table 2. Significant $(p<0.05)$ Spearman's rank order correlations for wildfire area burned and climate variable pairs for each month for each South Dakota Climate Division. Positive (negative) values for PMDI indicate significant rank correlations between abnormally wet (dry) periods and area burned, positive (negative) values of temperature (T) indicate significant rank correlations between above (below) average temperatures and area burned, and positive (negative) values of precipitation (P) indicate significant rank correlations between precipitation deficits (surpluses) and area burned. Asterisks (*) imply no significant correlation. See text and Table 1 for climate variable and subscript time-lag descriptions.

\begin{tabular}{|c|c|c|c|c|c|c|c|c|c|c|c|c|}
\hline & Jan. & Feb. & Mar. & Apr. & May & Jun. & Jul. & Aug. & Sep. & Oct. & Nov. & Dec. \\
\hline NW & * & * & $\begin{array}{l}-P_{i} \\
+T_{i}\end{array}$ & * & * & $\begin{array}{c}-P_{i} \\
+T_{i} \\
-P M D I_{i}\end{array}$ & $\begin{array}{c}-P_{i-1},-P_{i-3,},-P_{i-12} \\
+T_{i},+T_{i-1} \\
-P M D I_{i},-P M D I_{i-1}\end{array}$ & $+T_{i-1}$ & * & $\begin{array}{c}-P_{i-1} \\
+P_{i-12} \\
+P M D I_{i-1}\end{array}$ & $+T_{i}$ & $\begin{array}{l}-P_{i} \\
+T_{i}\end{array}$ \\
\hline $\mathrm{NC}$ & $+T_{i}$ & * & $+T_{i}$ & $-P_{i-3}$ & * & $-P_{i}$ & $-P_{i-3}$ & $-P_{i}$ & $-P_{i}$ & $+T_{i}$ & $+P M D I_{i-1}$ & $\begin{array}{l}-P_{i-1} \\
+T_{i}\end{array}$ \\
\hline $\mathrm{NE}$ & $-P_{i-3}$ & $+T_{i}$ & $+T_{i}$ & $\begin{array}{c}+T_{i-1} \\
-P M D I_{i} \\
\end{array}$ & $-P M D I_{i}$ & $\begin{array}{c}-P_{i-12} \\
-P M D I_{i},-P M D I_{i-1}\end{array}$ & $-P M D I_{i},-P M D I_{i-1}$ & * & * & * & $*$ & $\begin{array}{l}-P_{i} \\
+T_{i} \\
\end{array}$ \\
\hline BH & $+T_{i}$ & * & $+T_{i-1}$ & * & $-P_{i}$ & $\begin{array}{c}-P_{i},-P_{i-1},-P_{i-3} \\
-P_{i-12} \\
+T_{i} \\
-P M D I_{i},-P M D I_{i-1} \\
\end{array}$ & $\begin{array}{c}-P_{i-1},-P_{i-3,},-P_{i-12} \\
+T_{i}+,+T_{i-1} \\
-P M D I_{i},-P M D I_{i-1} \\
\end{array}$ & $\begin{array}{c}-P_{i-1,},-P_{i-3} \\
+T_{i-1}\end{array}$ & $+T_{i}$ & $-P_{i}$ & $\begin{array}{l}-P_{i-1} \\
+T_{i-1}\end{array}$ & $+T_{i}$ \\
\hline C & $\begin{array}{c}-P_{i-3} \\
-P M D I_{i-1}\end{array}$ & $+T_{i-1}$ & * & $\begin{array}{l}-P_{i-1} \\
-P_{i-3}\end{array}$ & * & $\begin{array}{l}-P_{i} \\
+T_{i}\end{array}$ & $\begin{array}{c}-P_{i-1} \\
+T_{i,}+T_{i-1} \\
-P M D I_{i}\end{array}$ & $\begin{array}{c}-P_{i} \\
+T_{i,}+T_{i-1} \\
-P M D I_{i}\end{array}$ & $\begin{array}{l}-P_{i} \\
-P_{i-1}\end{array}$ & $\begin{array}{l}-P_{i-1} \\
+T_{i}\end{array}$ & * & * \\
\hline EC & $*$ & $-P_{i-1}$ & $\begin{array}{l}-P_{i} \\
+T_{i}\end{array}$ & $\begin{array}{c}-P_{i-3} \\
-P M D I_{i-1}\end{array}$ & $-P_{i-12}$ & $\begin{array}{c}-P_{i} \\
+T_{i} \\
-P M D I_{i},-P M D I_{i-1} \\
\end{array}$ & $\begin{array}{c}-P_{i-1} \\
-P M D I_{i},-P M D I_{i-1}\end{array}$ & $-P_{i-12}$ & $-P_{i-1}$ & $\begin{array}{l}-P_{i-3} \\
-T_{i-1} \\
\end{array}$ & $*$ & $+T_{i}$ \\
\hline sW & $+T_{i}$ & $\begin{array}{l}-P_{i} \\
+T_{i}\end{array}$ & $*$ & * & $-P_{i}$ & $\begin{array}{c}-P_{i,}-P_{i-1} \\
+T_{i} \\
-P M D I_{i} \\
\end{array}$ & $\begin{array}{c}-P_{i,}, P_{i-1},-P_{i-3} \\
\quad+T_{i},+T_{i-1} \\
-P M D I_{i},-P M D I_{i-1}\end{array}$ & $\begin{array}{c}-P_{i-1},-P_{i-3} \\
+T_{i-1} \\
-P M D I_{i},-P M D I_{i-1}\end{array}$ & $\begin{array}{l}-P_{i-1} \\
-P_{i-3} \\
-P M D I_{i}\end{array}$ & $\begin{array}{l}-P_{i} \\
+T_{i}\end{array}$ & $+T_{i}$ & $-P_{i}$ \\
\hline SC & $*$ & $*$ & * & $\begin{array}{l}-P_{i-1} \\
-P_{i-3}\end{array}$ & * & $\begin{array}{c}-P_{i} \\
+T_{i} \\
-P M D I_{i},-P M D I_{i-1}\end{array}$ & $\begin{array}{c}-P_{i} \\
+T_{i,+}+T_{i-1} \\
-P M D I_{i}\end{array}$ & $-P_{i-1}$ & $*$ & $-P_{i-1}$ & $\begin{array}{c}+P_{i-12} \\
+P M D I_{i},+P M D I_{i-1}\end{array}$ & * \\
\hline $\mathrm{SE}$ & $-P M D I_{i}$ & * & $+T_{i}$ & $-P_{i-12}$ & $\begin{array}{l}-P_{i-1} \\
-P_{i-3}\end{array}$ & $-P_{i}$ & $\begin{array}{c}-P_{i} \\
+T_{i,}+T_{i-1} \\
-P M D I_{i}\end{array}$ & $-P_{i}$ & $-P_{i-1}$ & $+T_{i}$ & $-P_{i-1}$ & $*$ \\
\hline
\end{tabular}


Table 3. Significant $(p<0.05)$ Spearman's rank order correlations for wildfire ignitions and climate variable pairs for each month for each South Dakota Climate Division. Positive (negative) values for PMDI indicate significant rank correlations between abnormally wet (dry) periods and the number of ignitions, positive (negative) values of temperature $(\mathrm{T})$ indicate significant rank correlations between above (below) average temperatures and the number of ignitions, and positive (negative) values of precipitation $(\mathrm{P})$ indicate significant rank correlations between precipitation deficits (surpluses) and the number of ignitions. Asterisks $\left({ }^{*}\right)$ imply no significant correlation. See text and Table 1 for climate variable and subscript time-lag descriptions.

\begin{tabular}{|c|c|c|c|c|c|c|c|c|c|c|c|c|}
\hline & Jan. & Feb. & Mar. & Apr. & May & Jun. & Jul. & Aug. & Sep. & Oct. & Nov. & Dec. \\
\hline NW & * & * & $\begin{array}{l}-P_{i} \\
+T_{i}\end{array}$ & * & * & $\begin{array}{c}-P_{i} \\
+T_{i} \\
-P M D I_{i},-P M D I_{i-1}\end{array}$ & $\begin{array}{c}-P_{i-1},-P_{i-12} \\
+T_{i,}, T_{i-1} \\
-P M D I_{i},-P M D I_{i-1}\end{array}$ & $+T_{i-1}$ & $\begin{array}{l}-P_{i} \\
+T_{i}\end{array}$ & $-P_{i-1}$ & $*$ & $\begin{array}{l}-P_{i} \\
+T_{i}\end{array}$ \\
\hline NC & $+T_{i}$ & * & * & * & * & $\begin{array}{l}-P_{i} \\
+T_{i} \\
\end{array}$ & $+T_{i},+T_{i-1}$ & * & $-P_{i}$ & * & $\begin{array}{c}-P_{i},+P_{i-12} \\
+P M D I_{i}+P M D I_{i-1}\end{array}$ & $\begin{array}{c}-P_{i-1} \\
+T_{i} \\
\end{array}$ \\
\hline NE & $-P_{i-3}$ & $+T_{i-1}$ & $+T_{i}$ & $+T_{i-1}$ & * & $\begin{array}{c}+T_{i} \\
-P M D I_{i},-P M D I_{i-1} \\
\end{array}$ & $\begin{array}{c}-P_{i-12} \\
+T_{i-1} \\
-P M D I_{i},-P M D I_{i-1} \\
\end{array}$ & * & $\begin{array}{l}-P_{i},-P_{i-12} \\
-P M D I_{i}\end{array}$ & $\begin{array}{l}-P_{i} \\
+T_{i}\end{array}$ & $-P_{i-3}$ & $+T_{i}$ \\
\hline BH & $+T_{i}$ & $*$ & * & $*$ & $-P_{i}$ & $\begin{array}{c}-P_{i} \\
+T_{i} \\
-P M D I_{i}\end{array}$ & $\begin{array}{c}-P_{i-1},-P_{i-3},-P_{i-12} \\
+T_{i} \\
-P M D I_{i},-P M D I_{i-1}\end{array}$ & $\begin{array}{c}-P_{i-1} \\
+T_{i}+T_{i-1}\end{array}$ & $+T_{i},+T_{i-1}$ & $\begin{array}{l}-P_{i} \\
+T_{i}\end{array}$ & $+T_{i},+T_{i-1}$ & $+T_{i}$ \\
\hline C & $-P M D I_{i-1}$ & $+T_{i-1}$ & $+T_{i}$ & $-P_{i-3}$ & $*$ & $\begin{array}{c}-P_{i,}-P_{i-1} \\
+T_{i}\end{array}$ & $\begin{array}{c}-P_{i,}-P_{i-1} \\
+T_{i,}+T_{i-1} \\
-P M D I_{i} \\
\end{array}$ & * & $-P_{i}$ & $+T_{i}$ & $*$ & * \\
\hline $\mathrm{EC}$ & * & $-P_{i-1}$ & $\begin{array}{l}-P_{i} \\
+T_{i}\end{array}$ & $\begin{array}{l}-P_{i,} \\
-P_{i-1} \\
-P_{i-3} \\
\end{array}$ & * & $\begin{array}{c}-P_{i} \\
+T_{i} \\
-P M D I_{i},-P M D I_{i-1} \\
\end{array}$ & $\begin{array}{c}-P_{i},-P_{i-3,},-P_{i-12} \\
+T_{i-1} \\
-P M D I_{i},-P M D I_{i-1} \\
\end{array}$ & $-P M D I_{i}$ & $-P_{i},-P_{i-1}$ & $\begin{array}{l}-P_{i} \\
-P_{i-3} \\
-T_{i-1} \\
\end{array}$ & $-P_{i}$ & $+T_{i}$ \\
\hline SW & $+T_{i}$ & $+T_{i}$ & $+T_{i}$ & $*$ & $\begin{array}{c}-P_{i} \\
+T_{i} \\
-P M D I_{i}\end{array}$ & $\begin{array}{c}-P_{i,}-P_{i-1} \\
+T_{i},+T_{i-1} \\
-P M D I_{i}\end{array}$ & $\begin{array}{c}-P_{i,}-P_{i-1,1}-P_{i-3,}-P_{i-12} \\
+T_{i,}, T_{i-1} \\
-P M D I_{i},-P M D I_{i-1}\end{array}$ & $\begin{array}{c}-P_{i-1} \\
+T_{i},+T_{i-1}\end{array}$ & $-P_{i-1}$ & $+T_{i}$ & $*$ & $\begin{array}{l}-P_{i} \\
+T_{i}\end{array}$ \\
\hline SC & $*$ & $+T_{i}$ & $+T_{i}$ & * & $-P_{i}$ & $\begin{array}{c}-P_{i} \\
-P M D I_{i},-P M D I_{i-1}\end{array}$ & $-P_{i}$ & * & $-P_{i}$ & * & $\begin{array}{c}+P_{i-12} \\
+P M D I_{i}+P M D I_{i-1}\end{array}$ & $*$ \\
\hline SE & $-P M D I_{i}$ & $+T_{i-1}$ & $+T_{i}$ & $-P_{i}$ & * & $\begin{array}{c}-P_{i} \\
+T_{i} \\
-P M D I_{i},-P M D I_{i-1}\end{array}$ & $\begin{array}{c}-P_{i} \\
+T_{i-1} \\
-P M D I_{i}\end{array}$ & $-P_{i}$ & $-P_{i-1}$ & $-P_{i-3}$ & $-P_{i-1}$ & $+T_{i}$ \\
\hline
\end{tabular}




\section{Discussion}

Climatological conditions drive the wildland fuels conditions and therefore are a contributing factor in wildland fire spread and growth. However, these relationships are not necessarily similar across South Dakota or within the same area for different times of the year.

\subsection{Drought}

Abnormally dry conditions affect wildfire numbers and area burned primarily during the early summer months of June and July as seen from the significant negative correlations between the PMDI and wildfire data (Tables 2 and 3). Presumably, this is due to the annual growing cycle of the fine fuels. Grasses comprise the majority of the surface fuels (the main carrier of surface fire) within South Dakota and these fuels are likely too moist or green to be susceptible to ignition or to sustain wildfire spread under normal climatic conditions during early and mid-summer [37-39]. During prolonged drought periods, these types of plants may not sprout or become stressed curing earlier in their life cycles. If few green plants are present and sufficiently dry surface fuels remain from previous years, wildfire may have increased opportunity to become established and spread. The relationship between concurrent drought and an increase in wildland fires is well established in the literature [14,15,23,40-42].

There is a signal that during the fall months positive PMDI values (wetter than average conditions) may be related to an increase in wildfire activity in Climate Divisions 1 (Northwest), 2 (Northcentral), and 8 (Southcentral). It is possible that an increase in moisture over the preceding months leads to increases in fine fuel loadings. These larger fuels loadings then become receptive to wildfire after the climatologically normal killing frosts during the fall season. Such correlations within grassland fuel types have been noted for other regions of the United States [23].

Negative values of PMDI are not significantly related to either wildfire number or wildfire area burned across the majority of the climate divisions from September through March. The lack of a correlation between the two implies that drought conditions are not a necessary requirement for large wildland fires during months after killing frost events and before spring green-up-a period when the grasses are fully cured.

\subsection{Temperature}

Positive temperature anomalies are significantly correlated to both wildfire area burned and numbers of wildfires. A distinct pattern, however, does not appear to emerge with respect to location or seasonality. Positive temperature anomalies during the winter months may lead to less snowpack and exposed fuels leading to an increase in probability of ignition and wildfire spread. Increased temperatures during the warm months may stress the herbaceous fuels either causing them to enter dormancy earlier than usual or temporarily stalling growth. Numerous studies $[23,28,29]$ have come to similar conclusions noting correlations between increased temperatures and an increase in wildfire frequency and/or size. Statistically significant correlations were not seen for negative temperature anomalies for any climate division during any month in the data for area burned or numbers of fire starts.

\subsection{Precipitation}

Precipitation deficits, such as positive temperature anomalies, are well-correlated to wildfire activity across South Dakota during many months of the year. Short-term precipitation deficits may lead to dry or stressed fuels during the summer months while deficits during the winter months may lead to snow-free conditions allowing the surface fuels to be receptive to ignitions. Longer term precipitation deficits (three or more months) are best correlated to wildfire activity during the early summer months, similar to correlations seen in the PMDI data.

Within Climate Division 4 (Black Hills) 1-, 3-, and 12-month precipitation deficits are significantly correlated to wildfire activity during June and July. This climate division contains a larger spectrum of 
fuel types and sizes than do many of the prairie areas of South Dakota and therefore may respond differently than other locations to precipitation deficits. Fine fuels such as timber litter or grass are known to carry surface fire but the larger fuels such as dead and down material and logging slash likely increase the intensity of a wildland fire. The larger diameter fuels take more time than the fine fuels to respond to prolonged periods of wet or dry conditions, a concept known as the time lag principle [43]. The statistical correlation between wildfire activity and the extended precipitation deficits may be a reflection of the time lag principle for the heavier fuel types during these early summer months.

\subsection{Ignitions vs. Area Burned}

Many internally-similar patterns emerge within the results when comparing numbers of ignitions with the area burned data. The monthly distribution of wildfire ignitions follows a similar pattern to the area burned for nearly all of the climate divisions (Figure 3 and by extension Tables 2 and 3). It is reasonable to assume that the climatic conditions conducive to wildfire starts are also conducive to wildfire growth. An alternative or complementary hypothesis is that the probability of a large wildfire increases with the number of ignitions. A notable exception to this pattern is Climate Division 6 (Central) where the largest number of fire starts occur during July and August while the majority of the area is burned during September and October.

\subsection{Other Factors}

Previous research [44] has indicated that substantial changes in land use within South Dakota have occurred on the timescale of this study potentially influencing the results. From 2006 to 2012 grassland losses amounted to over 1.8 million acres while cropland gains were seen in excess of 1.4 million acres across South Dakota. This may alter the frequency and seasonality of wildfire due to changes in vegetative structure (i.e., composition, continuity, fuel loading and moisture) and human-related impacts (i.e., harvesting practices, grazing, land use, ignitions). Anthropogenic factors have been noted to confound others studying wildfire-climate relationships [40]. Additionally, this study may be impacted by changes due to a short-term variations in climate as annual rises in both precipitation and temperature have been noted in the Great Plains for the past several decades [45].

Eastern South Dakota has substantially more row crops than central or western portions of the state and the wildfire climatology across that region differs as well (see Figure 3). Central and south central South Dakota (as given by [44]) were shown to have the largest proportional increases of cropland as compared to other regions of the state. It is possible that, due to the changes in land cover, the peak in wildfire occurrence and area burned across central South Dakota may increasingly resemble that of eastern South Dakota with smaller fires occurring more often in the spring months.

Positive temperature anomalies were significantly correlated to wildfire activity across the state for most months (See Tables 2 and 3). It is likely that increases in temperature may result in additional wildfire activity in a future, warmer climate. However, anticipated precipitation increases may mitigate the issues presented by projected temperature increases. More research will be needed to explore these temperature-precipitation relationships for South Dakota.

\section{Conclusions}

South Dakota exhibits strong longitudinal variation in land cover, topography, and climate. These variations lead to the observed variations in fire frequency and area burned across the state. Fire activity in western South Dakota is highly dependent on recent climatic conditions such as temperature, precipitation, and drought. Drier and warmer conditions show significant correlation to wildfire activity during the summer months which, historically, is the peak fire season. Fire frequency and occurrence across central and eastern South Dakota exhibit less dependence on those same climate variables and fire activity is likely dictated more by short-term weather patterns and/or snow cover.

In areas where heavier fuels exist, drought, temperature, and accumulated precipitation appear to be well-correlated to wildfire activity. However, across the prairie of South Dakota, it appears that 
the fuels condition is what matters the most: fires are more numerous in the fall and spring when the fine fuels are typically cured or during the summer months under drought conditions. There are few significant correlations to positive precipitation anomalies and increases in area burned and/or increases in ignitions suggesting that the fuels in these areas, even in periods of drought, receive enough precipitation to grow sufficiently and carry wildfire. It is possible that factors not captured within this study such as human activity, topography, wind, and humidity play an equal or dominant role in wildfire occurrence and growth.

The results of this study demonstrate that the pyrogeography and wildfire-climate relationships may differ substantially over relatively small scales of space and time. If known, these relationships can be exploited to improve seasonal or monthly forecasts for wildfire potential aiding local wildfire managers. Future research is expected to include different climate-wildfire pairings in an attempt to find additional statistically significant correlations especially for the areas of central and eastern South Dakota. The results of this study and the results of additional research on climate-wildfire relationships may then be utilized to produce statistically-based forecasts for wildland fire potential.

Acknowledgments: This work was funded by the State of South Dakota through office of the State Fire Meteorologist. The author would like to thank Tyler Rehmeier and numerous land and wildfire managers for assistance in compiling the wildfire database. Comments from Andrew Detwiler and William Capehart were instrumental in the preparation of this work. The author would also like to thank three anonymous reviewers whose comments helped to clarify and improve the manuscript.

Conflicts of Interest: The author declares no conflict of interest.

\section{References}

1. Rohli, R.V.; Vega, A.J. Climatology, 2 ed.; Jones \& Bartlett Learning: Burlington, MA, USA, 2012; p. 425.

2. Johnson, E.A. Fire and Vegetation Dynamics: Studies from the North American Boreal Forest; Cambridge University Press: New York, NY, USA, 1992; p. 129.

3. Ryan, K.C. Global Change and Wildland Fire; U.S. Department of Agriculture, Forest Service, Rocky Mountain Research Station: Fort Collins, CO, USA, 2000; p. 257.

4. Flannigan, M.D.; Wotton, B.M. Climate, Weather, and Area Burned; Academic Press: San Diego, CA, USA, 2001; p. 594.

5. Guyette, R.P.; Muzika, R.-M.; Dey, D.C. Dynamics of an anthropogenic fire regime. Ecosystems 2002, 5, 472-486.

6. Yang, J.; He, H.S.; Shifley, S.R.; Gustafson, E.J. Spatial patterns of modern period human-caused fire occurrence in the Missouri Ozark Highlands. For. Sci. 2007, 53, 1-15.

7. Krawchuk, M.A.; Moritz, M.A.; Parisien, M.-A.; Van Dorn, J.; Hayhoe, K. Global pyrogeography: The current and future distribution of wildfire. PLoS ONE 2009, 4, e5102. [CrossRef] [PubMed]

8. Moritz, M.A.; Parisien, M.-A.; Batllori, E.; Krawchuk, M.A.; Van Dorn, J.; Ganz, D.J.; Hayhoe, K. Climate change and disruptions to global fire activity. Ecosphere 2012, 3, 1-22. [CrossRef]

9. Lehmann, C.E.; Anderson, T.M.; Sankaran, M.; Higgins, S.I.; Archibald, S.; Hoffmann, W.A.; Hanan, N.P.; Williams, R.J.; Fensham, R.J.; Felfili, J. Savanna vegetation-fire-climate relationships differ among continents. Science 2014, 343, 548-552. [CrossRef] [PubMed]

10. Jolly, W.M.; Cochrane, M.A.; Freeborn, P.H.; Holden, Z.A.; Brown, T.J.; Williamson, G.J.; Bowman, D.M. Climate-induced variations in global wildfire danger from 1979 to 2013. Nat. Commun. 2015, 6, 7537. [CrossRef] [PubMed]

11. Lucas, C.; Hennessy, K.; Mills, G.; Bathols, J. Bushfire weather in southeast Australia: Recent trends and projected climate change impacts. In Consultancy Report Prepared for The Climate Institute of Australia; Bushfire Cooperative Research Centre: Melbourne, Australia, 2007.

12. Riaño, D.; Moreno Ruiz, J.; Isidoro, D.; Ustin, S. Global spatial patterns and temporal trends of burned area between 1981 and 2000 using NOAA-NASA pathfinder. Glob. Chang. Biol. 2007, 13, 40-50. [CrossRef]

13. Bartlein, P.J.; Hostetler, S.W.; Shafer, S.L.; Holman, J.O.; Solomon, A.M. Temporal and spatial structure in a daily wildfire-start data set from the western United States (1986-96). Int. J. Wildland Fire 2008, 17, 8-17. [CrossRef] 
14. Westerling, A.L.; Gershunov, A.; Brown, T.J.; Cayan, D.R.; Dettinger, M.D. Climate and wildfire in the western United States. Bull. Am. Meteorol. Soc. 2003, 84, 595-604. [CrossRef]

15. Littell, J.S.; McKenzie, D.; Peterson, D.L.; Westerling, A.L. Climate and wildfire area burned in western US ecoprovinces, 1916-2003. Ecol. Appl. 2009, 19, 1003-1021. [CrossRef] [PubMed]

16. Donovan, V.M.; Wonkka, C.L.; Twidwell, D. Surging wildfire activity in a grassland biome. Geophys. Res. Lett. 2017, 44, 5986-5993. [CrossRef]

17. Lafon, C.W.; Hoss, J.A.; Grissino-Mayer, H.D. The contemporary fire regime of the central Appalachian Mountains and its relation to climate. Phys. Geogr. 2005, 26, 126-146. [CrossRef]

18. Maingi, J.K.; Henry, M.C. Factors influencing wildfire occurrence and distribution in eastern Kentucky, USA. Int. J. Wildland Fire 2007, 16, 23-33. [CrossRef]

19. Byram, G.M. Combustion of forest fuels. In Forest Fire: Control and Use; Davis, K.P., Ed.; McGraw Hill: New York, NY, USA, 1959; p. 686.

20. Deeming, J.E.; Lancaster, J.W.; Fosberg, M.A.; Furman, R.W.; Schroeder, M.J. National Fire-Danger Rating System; Rocky Mountain Forest and Range Experiment Station, Forest Service, US Department of Agriculture: Fort Collins, CO, USA, 1974; Volume 84, p. 64.

21. Prestemon, J.P.; Hawbaker, T.J.; Bowden, M.; Carpenter, J.; Brooks, M.T.; Abt, K.L.; Sutphen, R.; Scranton, S. Wildfire Ignitions: A Review of the Science and Recommendations for Empirical Modeling; US Department of Agriculture, Forest Service, Southern Research Station: Asheville, NC, USA, 2013; p. 24.

22. Van Wagtendonk, J.W. Fire as a Physical Process; University of California Press, Ltd.: Berkeley, CA, USA, 2006; p. 596.

23. Balling, R.C., Jr.; Meyer, G.A.; Wells, S.G. Relation of surface climate and burned area in Yellowstone National Park. Agric. For. Meteorol. 1992, 60, 285-293. [CrossRef]

24. Gedalof, Z.E.; Peterson, D.L.; Mantua, N.J. Atmospheric, climatic, and ecological controls on extreme wildfire years in the northwestern United States. Ecol. Appl. 2005, 15, 154-174. [CrossRef]

25. Abatzoglou, J.T.; Kolden, C.A. Relationships between climate and macroscale area burned in the western United States. Int. J. Wildland Fire 2013, 22, 1003-1020. [CrossRef]

26. Schoennagel, T.; Veblen, T.T.; Romme, W.H. The interaction of fire, fuels, and climate across Rocky Mountain forests. AIBS Bull. 2004, 54, 661-676. [CrossRef]

27. Crimmins, M.A.; Comrie, A.C. Interactions between antecedent climate and wildfire variability across south-eastern Arizona. Int. J. Wildland Fire 2005, 13, 455-466. [CrossRef]

28. Westerling, A.L.; Hidalgo, H.G.; Cayan, D.R.; Swetnam, T.W. Warming and earlier spring increase western US forest wildfire activity. Science 2006, 313, 940-943. [CrossRef] [PubMed]

29. Westerling, A.L.; Turner, M.G.; Smithwick, E.A.; Romme, W.H.; Ryan, M.G. Continued warming could transform greater Yellowstone fire regimes by mid-21st century. Proc. Natl. Acad. Sci. USA 2011, 108, 13165-13170. [CrossRef] [PubMed]

30. Spuhler, W.; Lytle, W.; Moe, D. Climate of South Dakota; Bulletin 582; South Dakota State University Agricultural Experiment Station: Brookings, SD, USA, 1971.

31. South Dakota State Office. South Dakota Land Use; USDA Natural Resources Conservation Service: Washington, DC, USA, 2013.

32. Guttman, N.B.; Quayle, R.G. A historical perspective of US climate divisions. Bull. Am. Meteorol. Soc. 1996, 77, 293-303. [CrossRef]

33. Heim, R.R., Jr. A review of twentieth-century drought indices used in the United States. Bull. Am. Meteorol. Soc. 2002, 83, 1149-1165. [CrossRef]

34. Heddinghaus, T.R.; Sabol, P. A review of the Palmer Drought Severity Index and where do we go from here. In Proceedings of the 7th Conference on Applied Climatology, Salt Lake City, UT, USA, 10-13 September 1991; pp. 242-246.

35. Mendenhall, W.; Sincich, T. Statistics for Engineering and the Sciences, 5th ed.; Prentice Hall, Inc.: Upper Saddle River, NJ, USA, 2007; p. 1060.

36. Bauman, P.; South Dakota State University Extension: Watertown, SD, USA. Personal communication.

37. Burgan, R.E. Estimating Live Fuel Moisture for the 1978 National Fire Danger Rating System; USDA Forest Service Research Paper INT-226; Intermountain Forest and Range Experiment Station: Ogden, UT, USA, 1979. 
38. Bradshaw, L.S.; Deeming, J.E.; Burgan, R.E.; Cohen, J.D. The 1978 National Fire-Danger Rating System: Technical Documentation; General Technical Report INT-169; US Department of Agriculture, Forest Service, Intermountain Forest and Range Experiment Station: Ogden, UT, USA, 1984; 44p.

39. White, M.A.; Thornton, P.E.; Running, S.W. A continental phenology model for monitoring vegetation responses to interannual climatic variability. Glob. Biogeochem. Cycles 1997, 11, 217-234. [CrossRef]

40. Swetnam, T.W.; Betancourt, J.L. Mesoscale disturbance and ecological response to decadal climatic variability in the American Southwest. J. Clim. 1998, 11, 3128-3147. [CrossRef]

41. Westerling, A.L.; Cayan, D.R.; Gershunov, A.; Dettinger, M.D.; Brown, T. Statistical forecast of the 2001 Western wildfire season using principal components regression. Exp. Long-Lead Forecast Bull. 2001, 10, 71-75.

42. Preisler, H.K.; Westerling, A.L. Statistical model for forecasting monthly large wildfire events in western United States. J. Appl. Meteorol. Climatol. 2007, 46, 1020-1030. [CrossRef]

43. Fuller, M. Forest Fires: An Introduction to Wildland Fire Behavior, Management, Firefighting, and Prevention; John Wiley \& Sons, Inc.: New York, NY, USA, 1991; p. 238.

44. Reitsma, K.D.; Dunn, B.H.; Smart, A.J. Estimated South Dakota Land Use Change from 2006 to 2012; South Dakota Board of Regents: Pierre, SD, USA, 2014; p. 4.

45. Kunkel, K.; Stevens, L.; Stevens, S.; Sun, L.; Janssen, E.; Wuebbles, D.; Kruk, M.; Thomas, D.; Shilski, M.; Umphlett, N. Regional Climate Trends and Scenarios for the US National Climate Assessment: Part 4. Climate of the US Great Plains; NOAA Technical Report NESDIS 142-4; US Department of Commerce, National Oceanic and Atmospheric Administration: Washington, DC, USA, 2013.

(C) 2018 by the author. Licensee MDPI, Basel, Switzerland. This article is an open access article distributed under the terms and conditions of the Creative Commons Attribution (CC BY) license (http:/ / creativecommons.org/licenses/by/4.0/). 